\title{
Does preoperative sleep quality and distress tolerance levels in cardiovascular surgery patients affect postoperative intensive care processes?
}

\author{
Tulin Yildiz ${ }^{1}$, Ebru Onler ${ }^{1}$, Utku Durgut ${ }^{1}$, Ozcan Gur $^{2}$, Selamı Gurkan ${ }^{2}$, Gunduz Yumun $^{2}$ \\ ${ }^{1}$ Surgical Nursing Department, Health School, Tekirdag Namık Kemal University, Tekurdag, Turkey \\ ${ }^{2}$ Cardiovascular Surgery Department, Faculty of Medicine, Tekirdag Namık Kemal University, Tekırdag, Turkey
}

Received: 2021-03-28.

Accepted: 2021-06-30

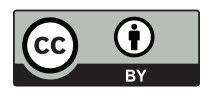

his work is licensed under a

Creative Commons Attribution 4.0 International License

J Clin Med Kaz 2021; 18(4):23-26

Corresponding author:

Tulin Yildiz.

E-mail: tyildiz70@hotmail.com

\begin{abstract}
Objective: This study was conducted to observe the effects of pre-operative sleep and distress intolerance levels on post-operative of cardiovascular surgery patients.

Material and methods: This is a descriptive study. The study population consisted of 120 patients who met the inclusion criteria and accepted to participate in this research. The data were collected by using tools such as the demographic data form which was developed by the researchers, Pittsburgh Sleep Quality Index (PSQI), Insomnia severity Index (ISI) and distress Interolerance index (DII), and applied through face to face interviews with the patients. The multivariate analysis of variance were used in the analysis of the data.

Results: This study was 120 patients, comprising 82 (68.3\%) males and 38 (31.7\%) females. According to PSQI, 77.5\% of patients have a poor sleep quality. Those with good sleep quality were found to have a lower total score (37.630)>=5 poor sleep quality than the total score (31.731) of the DII. According to the PSQI, as the sleep quality decreases, the intensive care unit (ICU) stay time is increasing (23.8\%, $p=0.009)$.

Conclusion: Compared to normal population, cardiovascular surgical patients have higher levels of poor sleep quality and distressing intolerance. We found a positive correlation between impaired sleep quality and distressed intolerance levels.
\end{abstract}

Key words: cardiac surgery, sleep pattern, distress interolerance, nursing care

\begin{abstract}
Introduction
Cardiovascular diseases (CVD) are first among the causes of morbidity, mortality and medical costs worldwide. Unhealthy eating habits such as tobacco use, excessive alcohol consumption, physical inactivity and excessive salt consumption are common risk factors in the development of cardiac diseases [1]. In addition to these risk factors, recent studies show that sleep problems are also effective in the development of CVD. Less than 6 hours of sleep increases the risk of CVD. In addition to various studies showing the effect of short sleep time, the effect of long-term sleep on the cardiovascular system has been investigated in recent years. Current evidence
\end{abstract}

suggests that disturbances in sleep patterns, such as short or long sleep duration, contribute to the development of CVD [2]. One study found that people who slept less than 7 hours per night had a $12 \%$ to $35 \%$ higher risk of death than those who slept more than 7 hours [3].

Sleep is considered as one of the basic physiological needs of human beings, which covers $1 / 3$ of human life and ensures health continuity [4-6]. A deterioration in health status can manifest itself with sleep disorders, as well as a deterioration in sleep patterns can have a direct impact on general health and life activities [6].

Sleep problems are a cause of stress for the body. Although stress is protective in the short term, constant 
stimulation causes pathological consequences in the long term. Chronic sleep deprivation provides over-stimulation of the sympathetic nervous system and Hypothalamus-PituitaryAdrenal (HPA) axis. With sympathetic nervous system activation, an increase in the release of adrenaline, noradrenaline and vasopressin, resulting in an increase in heart rate and blood pressure [7]. After activation of the hypothalamus, epinephrine and norepinephrine are released from the adrenal medulla.

Within the cardiovascular system, the increase in circulating catecholamines can result in hypertension, tachycardia and sometimes dysrhythmias [1]. While insomnia has been proven to alter biological phenotypes of deoxyribonucleic acid (DNA), ribonucleic acid (RNA), and protein levels, the underlying mechanisms have not been clearly demonstrated [8].

Sleep deprivation which emerging conditions contribute to the development of cardiovascular diseases such as vascular calcification, hypertension, atherosclerosis, arrhythmia, and myocardial infarction $[7,8]$.

Surgical interventions are widely used in health promotion and treatment of diseases. Surgery is a sudden event that affects people's physical and psychological well-being as well as their personalities, roles and family relationships [6].

As a challenge for patients, the surgical procedure brings pre-and postsurgical limitations, which can generate significant levels of anxiety [9]. Nurses have great responsibilities in order to maximize the well-being of patients prepared for surgical intervention, to have a successful operation and to ensure patient satisfaction. Improving sleep quality in the preoperative period and reducing the anxiety levels of patients before surgery is an undeniable important part of the holistic nursing approach [10].

\section{Material and methods Sample}

The population of this descriptive study $(n=120)$ consisted of patients who were hospitalised in the cardiovascular surgery clinic between November 2016 and May 2017. The study was planned to observe the effects of pre-operative sleep and distress intolerance levels on post-operative of cardiovascular surgery patients.

\section{Inclusion criteria}

- Patients who were diagnosed with cardiovascular diseases

- Aged 18 years or older

- Not having communication problems

- Patients who stayed at least 24 hours in ICU

\section{Exclusion criteria}

- Patients undergoing different surgery

- Patients taking sedatives, hypnotics, antidepressants and amphetamines

- Patients in shift work

\section{Data collection}

"Personal Information Form", Distress Intolerance Index (DII), Pittsburgh Sleep Quality Index (PSQI) and the Insomnia Severity Index (ISI) were used to collect data.

A questionnaire consisting of 4 sections was used to collect the research data.

The first section included "Personal Information Form" consisting of 11 questions related to patients' descriptive characteristics and their pre-operative and post-operative vital signs.
The second section included DII, developed by McHugh \& Otto [11] and adapted to Turkish by Çakır [12]. It is a 5-point Likert type form (1:Strongly Agree-5:Strongly Disagree) consisting of 10 items and one dimension. The scores from the scale range between 10 and 50 points. Low scores indicate a low level of intolerance.

The third section included the PSQI, developed by Buysse et al. [13] and adapted to Turkish by Agargün et al. (1996) [14]. A global PSQI score of 7 components greater than 5 indicates poor quality of sleep, while $0-4$ points indicate good quality of sleep.

The fourth section included the ISI, developed by Bastien et al. [15] and adapted to Turkish by Boysan et al. [16]. ISI is a self reported and 5-point Likert type scale and includes 7 items. Every item on the scale score between 0-4 points. Total scores range from 0 to 28 , with high scores indicating greater insomnia severity.

\section{Ethical Considerations}

To carry out this study, written institution permissions were obtained from the Tekirdag Namık Kemal University Medical Faculty Non-Interventional Clinical Research Ethics Committee numbered 2016/115/10/05.

\section{Data analysis}

The data was analysed using SPSS 24.0. Frequency, percentage, average, standard deviation, Kolmogorov Smirnov, Mann Whitney U, Kruskal Wallis, regression analysis and Spearman's correlation were used for data analysis. The statistical significance level was determined to be $p<0.05$.

\section{Results}

One hundred twenty patients were included into the study. 82 of these patients $(68 \%)$ were male and 38 of them $(32 \%)$ were female. The average age of the patients was $63.88 \pm 11.26$ years; of patients $41(34 \%)$ had their first operation, $79(66 \%)$ had previous surgical experience. Of the patients, 67(56\%) were smoking and 24(20\%) were drinking. Table 1 shows the general demographic features of the patients.

Patients had extubated after $9.12 \pm 3.51$ hours the transfer from the operation to the intensive care unit. Patients mobilized $17.08 \pm 0.351$ hours after transfer to the ICU. The duration of intensive care unit stay was $51.98 \pm 0.574$ hours (Table 2). But it was observed that the patients who smoked and alcohol had longer extubation times than the other patients.

High scores of DII indicate high tolerance to distress. The mean DII score of patients was 33.06 \pm 9.19 . A global PSQI score of greater than 5 indicates poor quality of sleep, while $0-4$ points indicate good quality of sleep. The mean PSQI of the patients was $7.17 \pm 3.70$ (Table 3 ). As the sleep quality of the patients decreased, their tolerance to distress decreased, too (Table 4).

There was a statistically significant difference across the sleep quality for total scores of DII $(t=3.03 ; p=0.003<0.05)$. DII scores of patients (37.630) with good sleep quality $(<5)$, were lower than distress intolerance scale scores of patients (31.731) with poor sleep quality $(>=5)$. In other words, those with poor sleep quality have a high tolerance for distress (Table 5).

There was no significant relationship between extubation and mobilization time and PSQI ( $p=0,200$ and $p=0,076)$, while PSQI was significantly correlated with ICU stay. Duration of ICU stay increases as sleep quality decreases $(23.8 \% ; \mathrm{p}=0.009)$ (Table 6). 

Patients $(n=120)$

\begin{tabular}{|l|l|l|l|l|l|}
\hline Min--Max & & & & & Mean \pm SD \\
\hline $\begin{array}{l}\text { Age } \\
63.88 \pm 11.26\end{array}$ & & & & & $22-85$ \\
\hline Characters & Frekans (n) & $\begin{array}{l}\text { Percentage } \\
(\%)\end{array}$ & Mean \pm SD & p \\
\hline Gender & Male & 82 & 63.3 & $63.2 \pm 12.1$ & 0.369 \\
\hline & Female & 38 & 31.7 & $65.2 \pm 9.2$ & \\
\hline BMI & Male & 82 & 63.3 & $27.6 \pm 1.6$ & 0.341 \\
\hline & Female & 38 & 31.7 & $27.2 \pm 1.5$ & \\
\hline Characters & & & Frekans (n) & $\begin{array}{l}\text { Percentage } \\
(\%)\end{array}$ & \\
\hline Marital status & Married & Single & 81 & 67.5 & \\
\hline & Total & 39 & 32.5 & \\
\hline & No & 120 & 100.0 & \\
\hline $\begin{array}{l}\text { Cigarette } \\
\text { smoking }\end{array}$ & Yes & 63 & 44.2 & \\
\hline & Total & 120 & 100.0 & \\
\hline & No & 96 & 80.0 & \\
\hline Alcohol use & Yes & 24 & 20.0 & \\
\hline & Total & 120 & 100.0 & \\
\hline & Yes & 79 & 65.8 & \\
\hline $\begin{array}{l}\text { Previous } \\
\text { Surgical } \\
\text { Experience }\end{array}$ & Total & 120 & 100.0 & \\
\hline & No & 41 & 34.2 & \\
\hline & & & & \\
\hline
\end{tabular}

Data are presented as number, percent, mean \pm standard deviation (SD) and range.

\section{Table 2}

Distribution of Patients According to Variation of Extubation (hours), Mobilization (hours) and Duration of Intensive Care Unit (hours)

\begin{tabular}{|l|l|l|l|}
\hline & $\mathrm{n}$ & Min-Max & Mean \pm SD \\
\hline $\begin{array}{l}\text { Extubation } \\
\text { Duration }\end{array}$ & 120 & $4-27$ & $9.12 \pm 3.51$ \\
\hline $\begin{array}{l}\text { Mobilization } \\
\text { Duration }\end{array}$ & 120 & $8-33$ & $17.08 \pm 0.35$ \\
\hline $\begin{array}{l}\text { ICU Length of } \\
\text { Stay }\end{array}$ & 120 & $21-64$ & $51.98 \pm 0.57$ \\
\hline
\end{tabular}

The data is presented as: $\mathrm{n}$, number; min-max, mean and standard deviation (SD) ICU: intensive care unit.

Table 3

\begin{tabular}{|l|l|l|l|}
\hline & $\mathrm{N}$ & Min-Max & Mean \pm SD \\
\hline $\begin{array}{l}\text { Distress } \\
\text { Intolerance } \\
\text { Index Total } \\
\text { Score }\end{array}$ & 120 & $12-50$ & $33.06 \pm 9.19$ \\
\hline $\begin{array}{l}\text { Pittsburgh Sleep } \\
\text { Quality Index }\end{array}$ & 120 & $2.00-16.00$ & $7.17 \pm 3.70$ \\
\hline
\end{tabular}

Table 4

The Relationship Between Total Score of Distress Intolerance Index and Pittsburgh Sleep Quality Index Total Score

\begin{tabular}{|l|l|l|}
\hline \multicolumn{2}{|l|}{} & $\begin{array}{l}\text { Pittsburgh Sleep } \\
\text { Quality Index }\end{array}$ \\
\hline $\begin{array}{l}\text { Distress Intolerance } \\
\text { Index Total Score }\end{array}$ & Pearson Correlation & $0.467^{* *}$ \\
\hline & Sig. (2-tailed) & 0 \\
\hline & N & 120 \\
\hline
\end{tabular}
to Total Score of Intolerance to Distress

\begin{tabular}{|l|l|l|l|l|l|}
\hline \multicolumn{2}{|c|}{} & $\mathrm{N}$ & Mean \pm SD & $\mathrm{t}$ & $\mathrm{p}$ \\
\hline $\begin{array}{l}\text { Distress } \\
\begin{array}{l}\text { Intolerance } \\
\text { Index Total } \\
\text { Score }\end{array}\end{array}$ & $\begin{array}{l}<5 \text { good } \\
\text { sleep quality }\end{array}$ & 27 & $22.37 \pm 8.9621$ & 3.034 & 0.003 \\
\cline { 2 - 6 } & $\begin{array}{l}>=5 \text { bad } \\
\text { sleep quality }\end{array}$ & 93 & $28.27 \pm 8.8724$ & & \\
\hline
\end{tabular}

Table 6

The Relationship Between Pittsburgh Sleep Quality Index Total Score and Extubation, Mobilization, and Intensive Care Stay Duration

\begin{tabular}{|l|l|l|}
\hline & \multicolumn{2}{|l|}{ Pittsburgh Sleep Quality Index } \\
\hline & $\mathrm{r}$ & $\mathrm{p}$ \\
\hline Extubation Duration & 0.118 & 0.2 \\
\hline Mobilization Duration & 0.163 & 0.076 \\
\hline ICU Length of Stay & 0.238 & 0.009 \\
\hline
\end{tabular}

\section{Discussion}

We found the compared to normal population, cardiovascular surgical patients have higher levels of poor sleep quality and distressing intolerance. We found a positive correlation between impaired sleep quality and distressed intolerance levels. Heart failure (HF) is seen that common worldwide [17]. It has been proven that sleep problems also increase morbidity and mortality. When the pain level and sleep problems of the patients undergoing open heart surgery are not controlled, the patient's comfort deteriorates, complications can develop more easily, and the recovery period and hospital stay may be prolonged [18]. Although surgical interventions are important for each patient group, the psychological effects of the surgery can be more intense when it comes to open heart surgery [19]. When the pain level and sleep problems of the patients undergoing open heart surgery are not controlled, the comfort of the patient deteriorates, complications can develop more easily, healing process and length of hospital stay may be prolonged. Inadequate information on the subject in the literature was the basis of this research. In this study, we aimed to determine the effect of preoperative sleep and intolerance to distress on postoperative patients in cardiovascular surgery patients. In Ibrahimoğlu's study, the mean of age revealed a sample 60 or close to 60 years. In experimental group $60 \%$ and in control group $66.7 \%$ were smokers [20]. When the mean age of studies is examined, it is seen that the results show similar characteristics with this study.

Although $100 \%$ of the patients had been mechanically ventilated, patients had extubated after $9.12 \pm 3.51$ hours the transfer from the operation to the ICU. Patients mobilized $17.08 \pm 0.351$ hours after transfer to the ICU. The duration of ICU stay was $51.98 \pm 0.574$ hours in this study. Postoperative complications also affect the duration of hospital stay and functional recovery. In this study show that the mean of PSQI the patients was $7.17 \pm 3.70$. As the PSQI score of the patients increased, sleep quality deteriorated, the total score of the tolerance to DII increased, tolerance decreased.

Sleep helps maintain a healthy balance of endocrine and immune systems [21]. In those who have sleep deprivation, this balance may not be maintained. Sauvet [22] demonstrated in a study of rats that 24-hour wakefulness caused a decrease in endothelial-dependent vasodilation not associated with changes in blood pressure or sympathetic activation [8]. Intubation and extubation can increase the concentration of catecholamines in the blood by stimulating the sympathetic nervous system 
and cause severe hemodynamic changes [20]. Tobaldini et al. demonstrated that arterial blood pressure (ABP) changes significantly after a 24-hour sleep loss [7]. In our study, it was determined that those with low sleep quality had a high tolerance to distress and as PSQI increased, the duration of stay in the ICU increased and sleep quality decreased. We believe it is important to maintain a pre-operative sleep pattern in patients undergoing cardiovascular surgery, and our current findings may be a trigger for future research into sleep deprivation.

\section{Conclusion}

Although surgical interventions are important for each patient group, the psychological effects of the surgery may be more intense when it comes to open heart surgery. Open heart surgery is a clinical process that affects the functions of all organs and systems in the body. Patients' existing sleep quality disorder and intolerance to distress are already deteriorated by the already poor quality of life sleep problems. Therefore, we think that close clinical follow-up of patients with poor sleep quality will decrease morbidity and mortality with applications that will improve sleep quality positively (medical treatment, psychosocial support, optimal environment).

Disclosures: There is no conflict of interest for all authors.

Acknowledgements: None.

Funding: None.

\section{References}

1. Calvin AD, Covassin N, Kremers WK, Adachi T, Macedo P, Albuquerque FN, et al., Experimental sleep restriction causes endothelial dysfunction in healthy humans, J. Am. Heart Assoc. 2014; 3:e1143. https://doi.org/10.1161/JAHA.114

2. Batista dos Santos MM, Martins A, Carlos J, \& Oliveira LMN. Anxiety, depression and stress in the preoperative surgical patient. Revista de Enfermagem Referência. 2014; 4(3):7-15. https://doi.org/10.12707/RIII1393

3. Liu H, Chen A. Roles of sleep deprivation in cardiovascular dysfunctions. Life Sciences. 2019; 219: 231-237. https://doi.org/10.1016/j. lfs.2019.01.006

4. Dalton A, Zafirova Z. Preoperative Management of the Geriatric Patient Frailty and Cognitive Impairment Assessment. Anesthesiology Clin. 2018; 36:599-614. https://doi.org/10.1016/j.anclin.2018.07.008

5. Öztürk M. Hastanede yatan yetişkin hastaların uygu gereksinimlerini etkileyen faktörlerin incelenmesi. Yüksek Lisans Tezi, Çukurova Üniversitesi Sağlık Bilimleri Enstitüsü. 2003, Adana

6. Uran G. Kırsal kesimde evde ve huzurevlerinde kalan 60 yaş üzeri yaşlılarda pittsburg uyku kalitesi indeksi ile uyku kalitelerinin karşılaştırılması. Yüksek Lisans Tezi, Gazi Üniversitesi Sağllk Bilimleri Enstitüsü, 2001, Ankara

7. Tobaldini E, Costantino G, Solbiati M, Cogliati C, Kara T, Nobili L, Montano N. Sleep, sleep deprivation, autonomic nervous system and cardiovascular diseases. Neuroscience and Biobehavioral Reviews. 2017; 74:321-329. https://doi.org/10.1016/j.neubiorev.2016.07.004

8. Redeker NS. Cardiovascular Disease. Edited Savard J and Ouellet MC. Chapter 5. Handbook of Sleep Disorders in Medical Conditions. 2019; 99-120. https://doi.org/10.1016/B978-0-12-813014-8.00005-6

9. Gonçalves KKN, Silva JI, Gomes ET,Pinheiro LLS, Figueiredo TR, Bezerra SMMS. Anxiety in the preoperative period of heart surgery. Rev Bras Enferm [Internet.] 2016; 69(2):374-80. https://doi.org/10.1590/0034-7167.2016690225i

10. Ayık C (2016). Ameliyat Öncesi Dönemde Aromaterapi Masajının Anksiyete Ve Uyku Kalitesine Etkisinin İncelenmesi, Hemşirelik Esasları Yüksek Lisans Tezi, Dokuz Eylül Üniversitesi Sağlık Bilimleri Enstitüsü 2016, İzmir

11. McHugh RK, \& Otto MW (2012). Refining the measurement of distress intolerance. Behavior Therapy. 43(3):641-651. doi: 10.1016/j. beth.2011.12.001

12. Çakır Z. Sıkıntıya Toleranssızlık Ölçeği ve Bilişsel-Davranışsal Kaçınma Ölçeğinin psikometrik özelliklerinin incelenmesi. Anatolian Journal of Psychiatry. 2016; 17(1):24-32

13. Buysse DJ, Reynolds CF 3rd, Monk TH, Berman SR, Kupfer DJ. The Pittsburgh Sleep Quality Index: a new instrument for psychiatric practice and research. Psychiatry Res. 1989; 28(2):193-213. doi: 10.1016/0165-1781(89)90047-4. PMID: 2748771.

14. Ağargün Y, Kara H, Anlar Ö Pittsburgh Uyku Kalitesi İndeksinin Geçerliği ve Güvenirliği. Türk Psikiyatri Dergisi. 1996; 7(2)

15. Bastien CH, Vallières A, Morin CM. Validation of the Insomnia Severity Index as an outcome measure for insomnia research. Sleep Med. 2001; 2(4):297-307. doi: 10.1016/s1389-9457(00)00065-4. PMID: 11438246.

16. Boysan, M., Güleç, M., Beşiroğlu, L. ve Kalafat, T. (2010). Uykusuzluk Şiddeti İndeksi’nin Türk örneklemindeki psikometrik özellikleri. Anadolu Psikiyatri Dergisi. 2010; 11:248-252.

17. Prochota B, Szwamel K, Uchmanowicz I. Socio-clinical variables affecting the level of self-care in elderly patients with heart failure. European Journal of Cardiovascular Nursing. 2019; 18(7):628-636. https://doi.org/10.1177/1474515119833251

18. Neher M, Nygårdh A, Per Nilsen P, Anders Broström A, Johansson P. Implementing internet-delivered cognitive behavioural therapy for patients with cardiovascular disease and psychological distress: a scoping review. European Journal of Cardiovascular Nursing. 2019; 18(5):346 - 357

19. Demir A, Akyurt D, Ergün B, Haytural C, Yiğit T, Taşoğlu İ, Elhan AH, Erdemli Ö. Kalp cerrahisi geçirecek olgularda anksiyete sağaltımı. Türk Göğüs Kalp Damar Cer Derg. 2010; 18(3):177-182

20. Ibrahimoğlu Ö, Kanan N. The Effect of Progressive Muscle Relaxation Exercises After Endotracheal Extubation on Vital Signs and Anxiety Level in Open Heart Surgery Patients. Turk J Intense Care. 2017; 15:98-106. https://doi.org/10.4274/tybd.04696

21. Aygin D, Sevim S. Acupressure on Anxiety and Sleep QualityAfter Cardiac Surgery: A Randomized Controlled Trial. Journal of PeriAnesthesia Nursing, 2019; 1-101

22. Sauvet F., Florence G., Van Beers P., Drogou C., Lagrume C., Chaumes C., et al., Total sleep deprivation alters endothelial function in rats: a nonsympathetic mechanism, Sleep. 2014; 37:465-473. https://doi.org/10.5665/sleep.347624587568. 